\title{
OBSERVATIONS ON THE CHLORIDE METABOLISM IN CONGENITAL PYLORIC STENOSIS
}

BY

\author{
NOAH MORRIS, M.D., and STANLEY GRAHAM, M.D.
}

(From the Department of Pædiatries, Glasgow University, and the Biochemical Laboratory, Royal Hospital for Sick Children, Glasgow.)

A fall in the chlorine content of the blood in cases of high intestinal obstruction is a well-recognized biochemical finding. The opinion is generally held that the diminution in the level of the blood chlorine is due primarily to the loss of chlorine by the vomitus. Accompanying this decrease in chlorine there is an increase in the $\mathrm{CO}_{2}$ content, resulting in a non-gaseous alkalosis with a diminution in the respiratory exchange. This increase in $\mathrm{CO}_{2}$ would appear to be the result of the body's effort to maintain the ionic concentration of the blood at the normal level, and simultaneously, to compensate the deficiency in the acid radicle. Very strong experimental proof has been brought forward by Gamble ${ }^{1}$ and others in favour of the truth of this hypothesis.

In a previous communication ${ }^{2}$ we have shown that the blood chlorine tends to be low in congenital pyloric stenosis, the diminution being roughly related to the severity of the vomiting. But we have seen cases in which there was present a typical picture of alkalosis, as indicated by the raised blood $\mathrm{CO}_{2}$ content and the depressed breathing, either during a period in which no vomiting occurred or, as in one instance, when there was a complete absence of vomiting. In Table 1 examples are given in which the depressed breathing was a feature despite the comparatively normal value for the blood chlorine. Incidentally, it shows that there is not necessarily a correlation between the

TABLE 1.

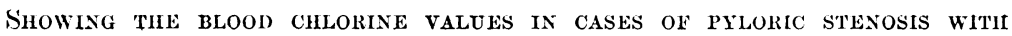
DEPRESSED BREATHING.

\begin{tabular}{|c|c|c|c|c|c|c|c|}
\hline \multirow[t]{2}{*}{ Name } & \multicolumn{2}{|c|}{ Blood chlorides } & \multicolumn{2}{|c|}{ Blood $\mathrm{CO}_{2}$} & \multirow{2}{*}{$\begin{array}{l}\text { Rate of } \\
\text { breathing }\end{array}$} & \multirow{2}{*}{$\begin{array}{l}\text { Degree of } \\
\text { vomiting }\end{array}$} & \multirow{2}{*}{$\begin{array}{l}\text { Urinary } \\
\text { chloride }\end{array}$} \\
\hline & mgrm. $\%$ & c.cm. N/10\% & Vol. \% & c.em. N/10\% & & & \\
\hline 'T.C. & 260 & $73 \cdot 2$ & $100 \cdot 8$ & $45 \cdot 0$ & $20 \mathrm{apn}$. & $++t$ & nil \\
\hline J.J. & 260 & $73 \cdot 2$ & $98 \cdot 8$ & $44 \cdot 1$ & $24 \quad$, & occas. & haze \\
\hline J.B. & 320 & $90 \cdot 1$ & - & - & $25 \quad$, & $+i$ & $\therefore$ \\
\hline \multirow[t]{2}{*}{ R.S. } & 260 & $73 \cdot 2$ & $107 \cdot 0$ & $47 \cdot 7$ & 21, & nil & nil \\
\hline & 320 & $90 \cdot 1$ & $102 \cdot 4$ & $45 \cdot 7$ & 20, & v. occas. & nil \\
\hline
\end{tabular}


increase in $\mathrm{CO}_{2}$ and the decrease in chlorine. Further, in our experience the raising of the blood chlorine to normal by the administration of saline, either intra-venously or otherwise, has never resulted in a definite fall in the $\mathrm{CO}_{2}$ content or a restoration of the breathing to normal. The last case (R.S.) is an example of the statement made above that an increase of $\mathrm{CO}_{2}$ and decrease of chlorine may occur during a prolonged absence of vomiting. Another point of interest is the absence of urinary chlorine despite a value for blood chlorine within normal limits. These instances, it must be admitted, are exceptions to the general findings of diminished chlorine accompanying symptoms. Nevertheless, several facts emerge which make one hesitate to assume that the findings in experimental intestinal obstruction hold good for pyloric stenosis in infancy.

Despite these findings of normal blood chlorine in a certain number of cases, we are convinced that the chlorine metabolism is definitely disturbed in congenital pyloric stenosis. We have published figures ${ }^{2}$ indicating that a very marked retention of chlorine takes place in this condition after parenteral administration of $\mathrm{NaCl}$, the retention greatly exceeding that which occurs in the normal infant as well as in infants who suffer from vomiting and depletion from any other cause. In general, it may be said that in pyloric stenosis never more than 20 per cent. of the amount injected leaves the body by the urine. It may be urged that this is due to the excessive excretion and loss of chlorine in the vomitus. In several instances, however, we have been fortunate enough to have had the opportunity of estimating the urinary chlorine excretion during periods when vomiting has been reduced to a minimum or even absent. These results are recorded in Table 2. It is remarkable that the greatest retention occurred when the vomiting was least (J.D. and R.M.).

TABLE 2.

Showing the percentage retention of chlorine during periods of mild vomiting OR ABSENCE OF VOMITING.

\begin{tabular}{|c|c|c|c|c|c|c|c|}
\hline \multirow[t]{2}{*}{ Name } & \multirow[t]{2}{*}{ Date } & \multirow{2}{*}{$\begin{array}{c}\text { Amount } \\
\text { of } \mathrm{NaCl} \\
\text { injected } \\
\text { grm. }\end{array}$} & \multirow{2}{*}{$\begin{array}{c}\text { Volume } \\
\text { of } \\
\text { urine }\end{array}$} & \multicolumn{2}{|c|}{$\mathrm{NaCl}$ excreted } & \multirow{2}{*}{$\begin{array}{c}\text { Percentage } \\
\text { retention } \\
\mathrm{Cl}\end{array}$} & \multirow{2}{*}{$\begin{array}{c}\text { Number } \\
\text { of } \\
\text { vomits }\end{array}$} \\
\hline & & & & Per cent. & Total & & \\
\hline \multirow[t]{2}{*}{ J.D.1 } & 24. 5.29 & & 220 & 0.059 & $0 \cdot 130$ & & 1 \\
\hline & 25. 5.29 & 1.08 & 170 & $0 \cdot 105$ & $0 \cdot 179$ & $95 \cdot 4$ & 0 \\
\hline \multirow[t]{2}{*}{2} & 3. 9.29 & & 800 & 0.012 & 0.096 & & 0 \\
\hline & 4. 9.29 & 0.99 & 536 & 0.023 & $0 \cdot 123$ & $97 \cdot 3$ & 0 \\
\hline \multirow{2}{*}{ J.R. } & 27. 4.29 & & 265 & 0.048 & $0 \cdot 128$ & & 2 \\
\hline & 28. 4.29 & 0.54 & 335 & 0.070 & $0 \cdot 232$ & $80 \cdot 7$ & 1 \\
\hline \multirow{2}{*}{ C.C. } & 17. 3.29 & & 232 & 0.0 & $0 \cdot 0$ & & 0 \\
\hline & 18. 3.29 & 0.99 & 350 & 0.047 & $0 \cdot 164$ & $83 \cdot 4$ & 2 \\
\hline \multirow{2}{*}{ R.M. } & 10.10 .29 & 0.90 & 67 & 0.006 & $0 \cdot 004$ & & 1 \\
\hline & 11.10 .29 & & 129 & 0.059 & 0.076 & $92 \cdot 0$ & 0 \\
\hline
\end{tabular}

In the cases of J.D. and R.M., the investigation took place after a period of four weeks during which there was comparatively litt'e vomiting. It is also interesting to note that in the second observation on J.D., the blood 
chlorine was 265 mgrm. per cent. ( $74 \cdot 6 \mathrm{c.cm}$. N/10 per cent.) prior to the intravenous injection of saline. It is evident, therefore, that the body retains chlorine in amounts exceeding the normal whether as a result of fixation in and about the tissues or because of inability to excrete the chlorine in the normal way. Further, the presence of normal values for the blood chlorine in two of the cases make it clear that the retention of chlorine may take place even when the blood has its full complement. It has been suggested by some that the renal excretion is defective and the presence of the high blood nonprotein nitrogen is adduced as evidence in favour of this view. In the first place a high blood non-protein nitrogen is by no means an invariable accompaniment of pyloric stenosis, although it is present in the most serious cases, whereas a disturbance in the chlorine metabolism, so far as we have observed, is a constant accompaniment of the condition. Also, we have on several occasions estimated the urea output and have found in all a normal percentage and total output of urea. In a few cases the retention of fixed base was determined after the injection of normal saline (Table 3).

TABLE 3.

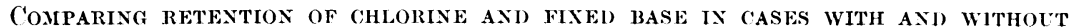
PYLORIC STENOSIS.

\begin{tabular}{|c|c|c|c|c|c|c|}
\hline \multirow[t]{2}{*}{ Name } & \multirow{2}{*}{$\begin{array}{c}\mathrm{NaCl} \\
\text { injected } \\
\text { (c.cm. } \mathrm{N} / 10)\end{array}$} & \multicolumn{2}{|c|}{$\begin{array}{l}\text { Na(l retained } \\
(\text { c.cm. } \mathrm{N} / 10)\end{array}$} & \multicolumn{2}{|c|}{$\begin{array}{l}\text { Fixed base retained } \\
\qquad(\text { c.cm. } \mathrm{N} / 10)\end{array}$} & \multirow[t]{2}{*}{ Remarks } \\
\hline & & Actual & $\begin{array}{l}\% \text { of extra } \\
\text { intake }\end{array}$ & Actual & $\begin{array}{l}\% \text { of extra } \\
\text { intake }\end{array}$ & \\
\hline J.R. & $9 \cdot 2 \cdot 3$ & $74 \cdot 3$ & $80 \cdot 7$ & $45 \cdot 6$ & $49 \cdot 4$ & Pyl. stenosis \\
\hline C. C. & $169 \cdot 0$ & $141 \cdot 0$ & $83 \cdot 4$ & $67 \cdot 0$ & $40 \cdot 0$ & , , , (before op.) \\
\hline , , & $154 \cdot 0$ & $1 \cdot 0$ & $0 \cdot 6$ & $28 \cdot 9$ & $18 \cdot 7$ & ,, ,, (after op.) \\
\hline B.W. & $154 \cdot 0$ & $2 \cdot 0$ & $13 \cdot 3$ & $50 \cdot 7$ & $33 \cdot 0$ & No pyl. stenosis \\
\hline
\end{tabular}

It is seen that the pyloric cases showed a much lower retention of the extra base than of the extra chlorine, whereas after operation and in the feeding case the reverse occurred. It would seem, therefore, that in pyloric stenosis there is a preferential retention of chlorine over fixed base, and that the reverse holds good in the non-pyloric cases.

Gamble and Ross ${ }^{1}$ have shown that in dogs with experimental occlusion of the pylorus there is a deficiency both of fixed base and chlorine, the latter being the more marked because of the presence of $\mathrm{HCl}$ in addition to the $\mathrm{BCl}$ in the vomitus. This explanation is not wholly satisfactory as in the cases detailed vomiting was very slight. Further, we have never been able to demonstrate the presence of free $\mathrm{HCl}$ in the stomach contents. Neutral chlorides, however, were always present. We would therefore suggest that the chlorine is retained in the body, partially at any rate, in a form other than $\mathrm{BCl}$.

Rominger and his co-workers ${ }^{3}$ have shown that in the normal infant more sodium than chlorine is retained after the administration of $\mathrm{NaCl}$. These 
same observers have also pointed out that chlorine may be retained apart from water-in other words, a dry retention of chlorine. In view of these findings with urea and fixed base it appears improbable that defective renal excretion provides an adequate explanation for the high retention of chlorine after parenteral administration of $\mathrm{NaCl}$.

These observations on the retention of chlorine led us to investigate the possibility of the existence of a partial chlorine vacuum in the tissues in the fatal cases. Considering the importance of chlorine to the body economy, remarkably few investigations appear in the literature as to the variation in the content of the tissues. Von Noorden ${ }^{4}$ gives 0.188 per cent. Cl $(52.9 \mathrm{c} . \mathrm{cm}$. $\mathrm{N} / 10$ ) as the average of the bodies of new-born infants, the extreme values being $0 \cdot 138$ per cent. and $0 \cdot 194$ per cent. Analyses of individual tissues in the human subject are rare. Observations have, however, been made on adult tissues by $\mathrm{Katz}^{5}$, Moraczewski ${ }^{6}$ and Hutchison ${ }^{7}$ who report figures varying from 0.070 per cent. ( 19.7 c.cm. N/10) in muscle to $0 \cdot 219$ per cent. $(61.7 \mathrm{c.cm}$. $\mathrm{N} / 10$ ) chlorine in lung. Since no figures pertaining to individual tissues of infants could be found, it was considered advisable to obtain normal standards for the chlorine content of the various tissues as well as to determine the chlorine content of the tissues in the fatal cases of pyloric stenosis. One appreciates, of course, that actually no truly normal tissues can be had, but from the post-mortem material of those cases in which there was no reason to suspect any such change as has been observed in pyloric stenosis, we obtained samples of various tissues. In all, tissues from six cases were analysed (Table 4).

TABLE 4.

SHOWIXg THE (HLORINE CONTENT OF THE VARIOCS TISSUES OF THE INFANT, EXPRESSEL IN C.C.I. $\mathrm{N} / 10$.

\begin{tabular}{|c|c|c|c|c|c|c|c|c|c|}
\hline Group & \multicolumn{3}{|c|}{ A } & \multicolumn{3}{|c|}{ B } & \multicolumn{3}{|c|}{ ( } \\
\hline \multirow[t]{2}{*}{ Tissue } & \multicolumn{3}{|c|}{$\begin{array}{l}\text { Normal cases } \\
\text { (six) }\end{array}$} & \multicolumn{3}{|c|}{$\begin{array}{c}\text { Pylories to whom no } \\
\text { saline has been given } \\
\text { ( } 4 \text { cases) }\end{array}$} & \multicolumn{3}{|c|}{$\begin{array}{c}\text { Pylorics to whom saline } \\
\text { had been given } \\
\text { ( } 4 \text { cases) }\end{array}$} \\
\hline & Max. & Min. & Aver. & Max. & Min. & Aver. & Max. & Min. & Aver. \\
\hline Muscle & $54 \pi$ & $38 \cdot 2$ & $43 \cdot 2$ & $31 \div$ & $20 \cdot 0$ & $24 \cdot 6$ & $69 \cdot 8$ & $46 \cdot 0$ & $60 \cdot 9$ \\
\hline Liver . & $4.5 \cdot 9$ & $25 \cdot 6$ & $36 \cdot 5$ & $30 \cdot 3$ & $17 \cdot 8$ & $23 \cdot 0$ & $67 \cdot 6$ & $3 \cdot 5$ & $50 \cdot 6$ \\
\hline Lunge .. & $6 \cdot 2 \cdot 5$ & $47 \cdot 5$ & $52 \cdot 4$ & $38 \cdot 6$ & $19 \cdot 1$ & $30 \cdot 7$ & $84 \cdot 8$ & $37 \cdot 6$ & $56 \cdot 6$ \\
\hline Heart . . & $41 \cdot 9$ & $32 \cdot 7$ & $37 \cdot 7$ & $16 \cdot 8$ & $16 \cdot 5$ & $16 \cdot 7$ & $48 \cdot 6$ & $2 \cdot 2 \cdot 2$ & $3 \cdot 2 \cdot 2$ \\
\hline Kidney & $44 \cdot 8$ & $39 \cdot 8$ & $4 \cdot 2 \cdot 1$ & $29 \cdot 2$ & $15 \cdot 9$ & $23 \cdot 0$ & $73 \cdot 2$ & $29 \cdot 0$ & $49 \cdot 2$ \\
\hline Brain . & $58 \cdot 5$ & $35 \cdot 9$ & $48 \cdot 9$ & $41 \%$ & $8 \cdot 2$ & $24 \cdot 9$ & $62 \cdot 8$ & $39 \cdot 7$ & $48 \cdot 9$ \\
\hline Nkin . . & $47 \cdot 7$ & $32 \cdot 5$ & $39 \cdot 2$ & $25 \cdot 2$ & $19 \cdot 1$ & $24 \cdot 5$ & $6 \pi \cdot 4$ & $39 \cdot 4$ & $56 \cdot 3$ \\
\hline
\end{tabular}

The method used in estimating the chlorine content of the tissues was the one elaborated by Van Slyke ${ }^{8}$. Portions of the various organs were obtained at the time of the post-mortem examination, and in each case were minced, mixed and weighed as soon as possible. All determinations were done in 
duplicate because of the possibility of error due to the unequal distribution of the tissue juices throughout the organ. Duplicates were consistent in all cases, the error never exceeding 10 per cent. and usually being much less. In Table 4, the results of the analysis of six such normal cases are shown (Group A) as well as the figures for the analysis of the tissues of eight fatal cases of pyloric stenosis in four of whom saline had been given (Group C) and four where no such treatment had been adopted (Group B). To conserve space, only the maximum, minimum and average figures have been quoted. One case, P.T. (Case 3), is not included in any group, since this infant, although not receiving any saline, had a very extensive broncho-pneumonia accompanied by a marked œdema.

The individual values of the various tissues in the cases of Groups B and C are given in Tables 5 and 6 .

TABLE :).

Showing the chlorine content (NaCl c.car. N/10\%) OF the variols tissces of

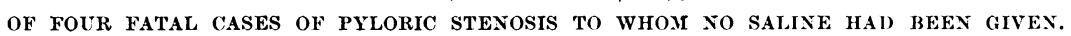

\begin{tabular}{lr|c|ccc|c|c|c}
\hline \multicolumn{2}{c|}{ Name } & Muscle & Liver & Lung & Heart & Kidney & Brain & Skin \\
\hline W.F. &. & $21 \cdot 6$ & $2 \cdot 2 \cdot 6$ & - & $16 \cdot 5$ & $20 \cdot 7$ & $8 \cdot 2$ & $25 \cdot 2$ \\
A.S. &. & $25 \cdot 4$ & $21 \cdot 2$ & $34 \cdot 4$ & - & $29 \cdot 2$ & - & $19 \cdot 1$ \\
J.L. &. & $20 \cdot 0$ & $17 \cdot 8$ & $19 \cdot 1$ & - & $15 \cdot 9$ & - & $19 \cdot 2$ \\
J.R. &. & $31 \cdot 5$ & $30 \cdot 3$ & $38 \cdot 6$ & $16 \cdot 8$ & $26 \cdot 3$ & $41 \cdot 5$ & - \\
\hline
\end{tabular}

TABLE 6.

Showing the chlorine content (NaCl c.cm. N/10\%) OF the tissubs of Folk

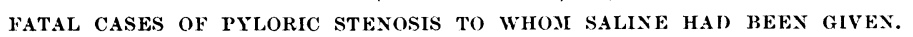

\begin{tabular}{|c|c|c|c|c|c|c|c|}
\hline Name & Muscle & Liver & Lung & Heart & Kidney & Brain & Skin \\
\hline T.C. & - & $32 \cdot 5$ & $37 \cdot 6$ & $22 \cdot 2$ & $29 \cdot 0$ & $39 \cdot 7$ & $39 \cdot 4$ \\
\hline .J.J. & $46 \cdot 0$ & $42 \cdot 2$ & $47 \cdot 5$ & $25 \cdot 7$ & $40 \cdot 5$ & $42 \cdot 4$ & $50 \cdot 2$ \\
\hline J.B. & $67 \cdot 1$ & $60 \cdot 2$ & 一 & $48 \cdot 6$ & $54 \cdot 1$ & $50 \cdot 7$ & $6 \pi \cdot 4$ \\
\hline R.S. & $69 \cdot 8$ & $67 \cdot 6$ & $84 \cdot 8$ & - & $73 \cdot 2$ & $6 \cdot 2 \cdot 8$ & $60 \cdot 0$ \\
\hline
\end{tabular}

It will be noted that in those cases not receiving saline the chlorine content is very greatly diminished, the maximal values of this group being usually below the minimal in the normals. These results point very convincingly to the existence of a diminished chlorine content of the tissues in cases of pyloric stenosis. Of the four cases of the last group, all of whom had been given saline, the route being intra-venous or intra-peritoneal or both, with the exception of one case in which the saline was given by mouth, high values were obtained, the average for this series exceeding the averages obtained for the control group. It must therefore be concluded that the administration of saline is capable of raising the diminished tissue chlorine content to normal or even to values above normal, 
In three patients œedema occurred during the course of the disease ; in two the œdema seemed to be related to the administration of the saline but in the third case, P.T. (Case 3), previously mentioned as not having been included in any group, no saline had been given. Administration of saline in similar amounts to healthy infants or to those suffering from gastro-enteritis rarely leads to the production of œdema, although a sudden rise in weight presumably due to a retention of water may occur. The anomaly of the presence in excess of a fluid rich in chlorine in the pericellular spaces during a condition which is characterized by chlorine impoverishment seems worthy of comment and investigation. The significant details of these three cases are therefore discussed.

Case 1.-J.B., a male infant aged six weeks had been vomiting since one week of age. He was a small emaciated infant weighing $4 \mathrm{lb} .13 \mathrm{oz}$. Visible gastrio peristalsis was present and a pyloric tymour was palpable. The breathing was shallow with definite apnœic periods. The rate was 25 per minute.

The progress of the case and the associated blood findings were as follows :-

13.11.29.-Admitted to ward. The blood examination revealed the following :-Total $\mathrm{CO}_{2}$ content : 83 vol. per cent. (28.0 c.cm. N/10 per cent.). Chlorides : 225 mgrm. per cent. (63.3 c.cm. N/10 per cent.). Non-protein nitrogen : $68 \mathrm{mgrm}$. per cent. The urine contained no chlorine. $100 \mathrm{c.cm}$. normal saline injected intra-venously.

14.11.29. - Feet puffy. $100 \mathrm{c.cm}$. normal saline injected intra-venously.

15.11.29.-Definite oedema present. $100 \mathrm{c.cm}$. normal saline injected intra-venously.

16.11.29.-Blood chlorine : $320 \mathrm{mgrm}$. per cent. (90.1 c.cm. N/10 per cent.). (Edema more marked. Breathing still shallow.

19.11.29. - Edema still present but much less than on 16th.

20.11.29. - No œdema. Blood chlorine : 320 mgrm. per cent. (90.1 c.cm. N/10 per cent.). $100 \mathrm{c.cm}$. normal saline injected intra-venously. Infant died.

At the commencement of the treatment, it seems safe to assume on the strength of the low blood chlorine content that there was a depletion of the chlorine content of the tissues. The first injection of normal saline led to a retention of 90.9 per cent. of the amount injected and simultaneously to the development of cedema. After 24 hours there was puffiness of the feet and the next day after the second injection, definite pitting on pressure. The ensuing injections of saline led to retentions of 86.8 per cent. and $56 \cdot 3$ per cent. respectively. In all, $2.7 \mathrm{grm}$. were injected and only $0.54 \mathrm{grm}$. excreted, i.e., a retention of 78 per cent. Yet this took place during the onset and definite increase of cedema. During this period there was an increase in weight of $206 \mathrm{grm}$., which approximates the weight of saline retained on the assumption that the $\mathrm{NaCl}$ was retained in a 0.9 per cent. solution. Thus, the weight of saline injected was roughly $300 \mathrm{grm}$., the weight of normal saline excreted was $66 \mathrm{grm}$., leaving $234 \mathrm{grm}$. retained. The urinary output of chlorine gradually increased to the period ending November 16th and was followed by a rapid decline accompanied by a diminution of the odema. On 19th, the weight was $57 \mathrm{grm}$. above that on 12th, while the total amount of intra-venously administered saline not lost in the urine was $1.49 \mathrm{grm}$. ,corresponding to $167 \mathrm{grm}$. of 0.9 per cent. $\mathrm{NaCl}$ solution. Two possibilities as to the reason for this discrepancy offer themselves. Either the retention of $\mathrm{NaCl}$ might have been only apparent, the loss taking place through the vomitus 
or the chlorine might have been stored apart from water. It was unfortunately impossible to collect the vomitus accurately, but on one day during which the vomiting was the most marked of the period an attempt was made and the collection yielded $200 \mathrm{mgrm}$. of $\mathrm{NaCl}$. As it was believed that approximately only half the vomitus was obtained, this would mean a loss by the vomiting of $400 \mathrm{mgrm}$. daily and for the six day period, $2 \cdot 4 \mathrm{grm}$. whereas the amount not excreted by the urine over the same period was $1.5 \mathrm{grm}$. It is possible therefore that the extra chlorine was lost in the vomiting. However, the tissues were found to have a very high value for chlorine, varying from 0.266 per cent. (67.1 c.cm. $\mathrm{N} / 10$ per cent.) in heart muscle to $0 \cdot 172$ per cent. $(48.6 \mathrm{c.cm}$. $\mathrm{N} / 10$ per cent.) in lung. With the exception of the brain all were above the maximum values for the control series. The saline given prior to the death of the infant contained $0.9 \mathrm{grm} . \mathrm{NaCl}(15.4 \mathrm{c.cm}$. N/10 per cent.) which could not possibly have raised the chlorine content of the tissues to such an extent.

In any case, whatever the amount lost by the vomiting, this infant stored chlorine in the tissues to a degree far exceeding the normal. That the storage of chlorine had taken place prior to the last injection of saline is indicated by the high normal blood chloride value (320 mgrm. per cent., $90 \cdot 1 \mathrm{c.cm} . \mathrm{N} / 10$ per cent.) previous to the last injection.

This case also raises the question of why the urinary output of chlorine was so low in the presence of œdema. Evidence of impairment of renal function could not be obtained. The defect in metabolism would appear to be in the tissues themselves. The picture presented resembles that seen in 'nephrosis' where the chlorine appears in minimal quantities in the urine although the power of excreting nitrogenous substances seems quite unimpaired. The first injection of saline would, owing to the depletion of the tissue chlorine lead to an outpouring of chlorine from the blood to the tissue. This outpouring would, however, go beyond the equilibrium point, a state of affairs that is well known in in vitro experiments, and which would take some time to adjust itself. Next day, in spite of the now partially replete tissue chlorine, the intra-venous injection of more saline, by suddenly raising the blood chlorine would again lead to the passage of chlorine to the tissues beyond the equilibrium point. The third injection would still further increase the amount of chlorine in the tissues. Forty-eight hours after the last injection of saline, the oedema commenced to disappear but without the simultaneous excretion of chlorine by the urine. Some of the chlorine was lost in the vomitus and some was retained in the tissues as revealed by the post-mortem analysis. Whatever the proportion retained, one is forced to the conclusion that the chlorine was present either in the tissues or the blood, or both, in a form which can only be excreted with difficulty by the kidney. The fact that prior to the injection of saline the blood chlorine content was 320 mgrm. per cent. $(90 \cdot 1 \mathrm{c.cm}$. N/10 per cent.) while the urinary chlorine was fractional in amount would suggest that the fault is either in the blood or the kidney.

It should also be mentioned that although the chlorine content of the blood on November 16th was slightly above normal the shallow breathing persisted. Unfortunately the $\mathrm{CO}_{2}$ was not estimated, but the presence of the 
depressed breathing is sufficient to raise doubt regarding the diminution of the blood chlorine being the sole factor in the production of the alkalosis. One might suggest that part of the chlorine was not united to base, thereby leaving an excessive amount of the latter to unite with $\mathrm{CO}_{2}$. It seems to us that only by assuming that a portion of the chlorine is not united to base can one explain, first, the depressed breathing accompanied by a high $\mathrm{CO}_{2}$, and secondly, the fact that chlorine does not appear in the urine although the body seems to have its full quota. The urinary findings in this case are given in Table 7.

TABLE 7.

Showing the URINARY Findings in Case 1 (J.B.) aNi) The Percentage Retention of Na(l after intra-venous in.JECTION OF NORMaL SALINE.

\begin{tabular}{|c|c|c|c|c|c|c|c|c|c|}
\hline \multicolumn{4}{|c|}{$\begin{array}{c}\text { Date } \\
(\text { Nov. 1929) }\end{array}$} & $\begin{array}{c}\text { Volume } \\
\text { of } \\
\text { urine }\end{array}$ & $\begin{array}{c}\text { Urinary } \\
\mathrm{NaCl} \\
\%\end{array}$ & $\begin{array}{l}\text { Urinary } \\
\mathrm{NaCl} \\
\text { total }\end{array}$ & $\begin{array}{c}\mathrm{NaCl} \\
\text { injected } \\
\text { intra-ven. } \\
\text { grm. }\end{array}$ & 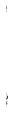 & $\begin{array}{c}\text { Percentage } \\
\text { retention } \\
\text { of } \mathrm{NaCl}\end{array}$ \\
\hline $12-13$ & . & .. & $\ldots$ & 82 & nil & nil & 一 & & - \\
\hline $13-14$ & . & . & $\ldots$ & 100 & 0.0819 & 0.0819 & 0.9 & & $90 \cdot 9$ \\
\hline $14-15$ & $\ldots$ & . & $\ldots$ & 91 & $0 \cdot 1304$ & $0 \cdot 1187$ & 0.9 & & $86 \cdot 8$ \\
\hline $15-16$ & . & . & . & 105 & $0 \cdot 3744$ & $0 \cdot 3931$ & 0.9 & & $56 \cdot 3$ \\
\hline $16-17$ & . & . & .. & 93 & $0 \cdot 3159$ & $0 \cdot 2937$ & - & & - \\
\hline $17-18$ & . & . & . & 71 & $0 \cdot 2457$ & 0.1743 & 一 & & 一 \\
\hline $18-19$ & $\cdots$ & . & . & 60 & $0 \cdot 2340$ & $0 \cdot 1404$ & - & & - \\
\hline $19-20$ & . & . & . & 39 & $0 \cdot 3276$ & 0.1278 & $\longrightarrow$ & & $\longrightarrow$ \\
\hline $20-20$ & . & . & . & 59 & 0.5850 & $0 \cdot 3452$ & 0.9 & & $75 \cdot 8$ \\
\hline
\end{tabular}

Case 2.-R.M., a male infant came under observation at the age of six weeks with a history of expulsive vomiting since two weeks of age. Gastric peristalsis was visible and a pyloric tumour readily palpable. The breathing was depressed with apnoic periods.

On admission the blood findings were as follows:-

Total $\mathrm{CO}_{2}$ content : $114.8 \mathrm{vol}$. per cent. (5l.2 c.cm. N/10 per cent.). (hlorine content : 190 mgrm. per cent. (53.5 c.cm. N 10 per cent.). Non-protein nitrogen : $57.6 \mathrm{mgrm}$. per cent.

The injection of $50 \mathrm{c.cm}$. normal saline led to an increased output of chlorine in the urine equivalent, however, to only $\mathbf{2 \cdot 7}$ per cent. of the extra intake. A week later, four daily intravenous injections of saline were given. Just before the commencement of this treatment the blood examination yielded the following figures :-

Total $\mathrm{CO}_{2}$ content : $121.6 \mathrm{vol}$. per cent. $(54 \cdot 3 \mathrm{c.cm} . \mathrm{N} / 10$ per cent.). Chlorine content : $230 \mathrm{mgrm}$. per cent. (64.8 c.cm. N/10 per cent.). Non-protein nitrogen : $57.6 \mathrm{mgrm}$. per cent.. and between the third and fourth injections the findings were :-

Total $\mathrm{CO}_{2}$ content: 69.6 vol. per cent. $(31.0 \mathrm{c.cm} . \mathrm{N} / 10$ per cent.). (hlorine content : 270 mgrm. per cent. ( 76.0 c.cm. N/10 per cent.). Non-protein nitrogen : $32 \mathrm{mgrm}$. per cent.

The output of chlorine was very low, averaging only $0.048 \mathrm{grm}$. per day over a period of ten days, and there was a rapid rise in weight which was associated with the presence of considerable œdema (pitting on pressure). The vomiting was fairly severe but apparently not sufficient to get rid of the chlorine in the œdematous fluid. Despite the almost normal chlorine content of the blood on the second last day, the amount of $\mathrm{NaCl}$ excreted was only $0.062 \mathrm{grm}$. About a month later the blood chlorine was $305 \mathrm{mgrm}$. per cent. $(86.0$ c.cm. $\mathrm{N} / 10$ per cent.) and the daily output in the urine only amounted 
to $0.004 \mathrm{grm}$. and given after the injection of $100 \mathrm{c.cm}$. of normal saline, this was only increased to $0.076 \mathrm{grm}$. although vomiting only occurred once. This infant made an uninterrupted recovery without operation and on dismissal was excreting as much as $1.0 \mathrm{grm}$. $\mathrm{NaCl}$ daily. It would therefore seem that during the active stage of pyloric stenosis the chlorine is present in some form that cannot be excreted by the kidney.

Case 3.-P.T., a male infant thirteen weeks of age came under observation because of vomiting which had begun at one month of age. Visible gastric peristalsis seen and a pyloric tumour palpable. The infant was acutely ill on admission with a broncho-pneumonia involving both lungs. On admission, Dec. 23rd, 1929, the blood analysis yielded the following figures :-

Total $\mathrm{CO}_{2}$ content : $95.4 \mathrm{vol}$. per cent. $(42.6 \mathrm{c.cm} . \mathrm{N} / 10$ per cent.). Chlorine content : $230 \mathrm{mgrm}$. per cent. $(64.8 \mathrm{c.cm}$. N/10 per cent.). Non-protein nitrogen : $68.2 \mathrm{mgrm}$. per cent.

The vomiting was marked on the two following days but slight on Dec. 25th. On the 26th there was an increase in weight of $115 \mathrm{grm}$. and on the 27 th of $145 \mathrm{grm}$. Simultaneously with this increase in weight, the vomiting ceased and did not recur. On the 27th slight œdema of the feet was noticed. This cedema gradually increased and before death there was well-marked redema of both feet and lumbar region. Analysis of the tissues revealed the chlorine content of the tissues to be within normal limits.

This case illustrates the development of œedema without the parenteral introduction of saline. It is possible that the pneumonic condition as such led to the odema. In lobar pneumonia, a retention of chlorine with increase in weight is a well-recognized phenomenon. The broncho-pneumonia involved all lobes of the right lung and the lower lobe of the left lung while the upper lobe was the seat of acute emphysema. It may be that the extensive consolidation rendered difficult the escape of $\mathrm{CO}_{2}$ which accordingly would be retained and probably displace the chlorine. The chlorine would be either passed to the tissues or lost by the vomit in order to make room for the excess $\mathrm{CO}_{2}$. It will, however, have been noted that the rise in weight dates from the cessation of the vomiting and in view of these facts it is suggested that the chlorine from the $\mathrm{BCl}$ of the blood is shunted to the tissue spaces. Once in the tissue spaces, despite the gradual repletion of the tissue chlorine, the base chlorine cannot get back into the blood stream in sufficient amount to be excreted by the kidney owing to the fact that the $\mathrm{CO}_{2}$ is holding up the base. Here again it is necessary to postulate either a renal defect or the presence of the chlorine in a form which cannot be dealt with by the kidneys.

The following case is briefly discussed because it lends additional support to the theory that the chlorine is present in a form other than $\mathrm{BCl}$.

Case 4.-R.S., a female infant, came under observation at the age of 8 weeks. Vomiting had begun at the age of 3 weeks. Visible gastric peristalsis was present and a pyloric tumour palpable. The blood examination at this time was as follows :-

Total ( $\mathrm{O}_{2}$ content: $152.0 \mathrm{vol}$. per cent. $(67.9 \mathrm{c.cm} . \mathrm{N} / 10$ per cent.). ('hlorine content: 200 mgrm. per cent. (56.3 c.cm. N/10 per cent.). Non-protein nitrogen : $57 \cdot 1 \mathrm{mgrm}$. per cent.

During the first fortnight in hospital the infant was given frequent intra-venous and intraperitoneal injections of normal saline as well as saline by the mouth, and although vomiting was frequent no odema was noted. The rise in weight following each injection was only temporary lasting usually not longer than one day. The blood chlorine, however, did increase and this was accompanied by a fall in the total $\mathrm{C}^{\circ} \mathrm{O}_{2}$ content. Three weeks after admission the blood was as follows :-

Total $\mathrm{CO}_{2}$ content : $65 \cdot 3$ vol. per cent. $(29 \cdot 1 \mathrm{c.cm} . \mathrm{N} / 10$ per cent. (hlorine content: $305 \mathrm{mgrm}$. per cent. (86.0 c.cm. N/10 per cent.). Non-protein nitrogen : $65 \mathrm{mgrm}$. per cent. 
Before the death of the infant the value for the blood chlorine was 380 mgrm. per cent. (107.0 c.cm. N/10 per cent.) an amount definitely in excess of normal. Although the chlorine content of the blood was more than replete, the breathing remained depressed. The analysis of the tissues for chlorine revealed very high values. It is difficult to understand how the great retention of chlorine took place without any signs of obvious œdema if the retention was in the form of inorganic chlorine. The urine was examined on several occasions and even when the blood chlorine content was high, it only contained a trace of chlorine. This finding by itself would lead to the conclusion that the chlorine must have been in great part present in a form other than $\mathrm{BCl}$. The association of these various phenomena, namely the high chlorine content of the blood and tissues with no odema, and the absence of more than a trace of chlorine in the urine seems to lead to no other conclusion.

\section{Summary.}

The observations recorded in the foregoing pages appear to justify the following conclusions :-

1. In untreated pyloric stenosis there is a partial chlorine vacuum in the tissues. This can be corrected by the administration of saline which, if continued, frequently leads to an excessive retention of chlorine and the production of odema, even when the chlorine content of the blood is normal. In such cases the chlorine content of the tissues is higher than normal.

2. Restoration of the blood chlorine content to normal does not result in a correstion of the alkalosis as is evidenced by the persistence of the high total $\mathrm{CO}_{2}$ content and the depressed breathing.

3. A normal blood chlorine content may be accompanied by a fractional amount of chlorine in the urine.

4. To permit of a satisfactory explanation of these findings, it appears necessary to postulate either (1) the inability of the kidney to excrete chlorine : or (2) more probably, in view of the findings with urea and fixed base, the presence of chlorine in the tissues in a form other than $\mathrm{BCl}$. Certain evidence is brought forward in support of the latter view.

We desire to express our thanks to the Medical Research Council by which the expenses of this investigation were defrayed.

\section{REFERENCES,}

1. Gamble, J. L., \& Ross, S. G., J. Clin. Invest., Baltimore, 1924-25, I, 403.

2. Graham, S., \& Morris, N., Arch. Dis. Childh., Lond., 1929, IV, 335.

3. Rominger, E., Bərger, I., \& Meyer, H., Zeit. f. Kinderh., Berlin, 1929, XLVIII, 43.

4. Von Noorden, C., Metabolism and Pract. Med., Lond., 1907, I. 416.

5. Katz, A., Arch.f. d. ges. Physiol., Bonn, 1896, LXIII, 1.

6. Moraczewski, D., Zeit.f. physiol. Chem., Strassburg, 1897, XXIII, 483.

7. Hutchison, R., J. Path. Bact., Lond., 1898, V, 406.

8. Van Slyke, D. D., J. Biol. Chem., Baltimore, 1923, LVIII, 523. 